\title{
Influence of deficit irrigation on nutrient indices in wine grape (Vitis vinifera L.)
}

\author{
Krista Shellie ${ }^{1^{*}}$, Brad Brown $^{2}$ \\ ${ }^{1}$ US Department of Agriculture, Agricultural Research Service, Horticultural Crops Research Laboratory, Parma, USA; \\ *Corresponding Author: Krista.Shellie@ars.usda.gov \\ ${ }^{2}$ Parma Research and Extension Center, University of Idaho, Parma, USA
}

Received 9 November 2011; revised 15 December 2011; accepted 23 January 2012

\begin{abstract}
Deficit irrigation is widely used in wine grape production (Vitis vinifera L.) to meet wine quality goals yet its influence on tissue nutrient indices has not been well studied. The objective of this research was to determine whether response to water deficit compromised the prescriptive usefulness of tissue nutrient analyses. Tissue macro and micronutrient composition at bloom and veraison were evaluated over multiple seasons in nine wine grape cultivars grown under wellwatered or deficit-irrigated conditions. Deficitirrigated vines sampled at veraison had 2 to 12 fold higher petiole nitrate-nitrogen concentration, $6 \%$ lower blade nitrogen concentration and $13 \%$ lower blade copper concentration compared to well-watered vines. Water deficit influenced blade potassium concentration at veraison differently according to cultivar and was lower (cv. Malbec, Petite syrah, Viognier, Lemberger and Sangiovese), higher (cv. Merlot, Cabernet franc and Cabernet Sauvignon) or simiIar (cv. Grenache) to well-watered vines. Results from this study indicate that nutrient analysis of petiole or blade tissue sampled at veraison has limited diagnostic and prescriptive usefulness when vines are grown under a water deficit.
\end{abstract}

Keywords: Nitrate Nitrogen; Potassium; Plant Water Status; Leaf Water Potential;

Evapotranspiration

\section{INTRODUCTION}

Wine grape (Vitis vinifera L.) is often intentionally grown under a water deficit to meet wine quality goals [1-5]. Above ground drip is the most widely used irrigation method for wine grape [6] and it facilitates manipulation of vine water status by providing temporal and spatial control of the wetted area within a vine row [7]. Reduced soil moisture, resulting from deficit irrigation, decreases vine nutrient uptake by reducing the transpiration stream and by limiting diffusion of nutrients to root surfaces [8]. The influence of deficit-irrigation and vine water status on grape tissue nutrient concentration is seldom reported in the literature and it remains unknown whether the influence of water deficit on tissue nutrient composition is similar among different cultivars of wine grape.

The nutrient composition of leaf petiole or blade tissue is widely used as a diagnostic or prescriptive tool to interpret vine nutrient status and to guide nutrient management practices [9-11]. Grape petiole nitrate-nitrogen $\left(\mathrm{NO}_{3}-\mathrm{N}\right)$ concentration at bloom is considered an indicator of plant nitrogen status with values below $350 \mathrm{mg} \cdot \mathrm{kg}^{-1}$ interpreted as deficient, 500 to $2000 \mathrm{mg} \cdot \mathrm{kg}^{-1}$ as adequate and above $2000 \mathrm{mg} \cdot \mathrm{kg}^{-1}$ as excessive [9,11]. Interpretation is, however, problematic because tissue nutrient concentration is influenced by cultural (cultivars, crop management) and environmental (moisture stress) factors in addition to soil nutrient accessibility [8]. Given the widespread use of deficit irrigation for wine grape, there has been surprisingly little focus on how water deficit affects the interpretation of tissue nutrient levels.

Appropriate interpretation of tissue nutrient analyses relies upon an understanding of cultivar-specific nutrient requirements and knowledge of how production practices influence tissue nutrient levels. This issue becomes even more important when a production practice is employed, such as deficit-irrigation, which intentionally induces a stress to the plant. Wine grape cultivars can differ in tissue nutrient composition [12-15], particularly in nitrogen $(\mathrm{N})$ and potassium $(\mathrm{K})$. Nitrate reductase (NR) activity can also differ among cultivars [16] and will presumably affect tissue $\mathrm{NO}_{3}-\mathrm{N}$ concentration under stress conditions. It is unknown whether differences among cultivars are associated with unique genotypic nutrient thresholds or genotype specific responses to environmental factors. The objective of this 
research was to determine whether vine exposure to water deficit compromised the diagnostic and prescriptive usefulness of petiole and blade nutrient analyses for nutrient management decision making.

\section{MATERIALS AND METHODS}

\subsection{Field Site and Plant Material}

The trial was conducted over four growing seasons (2002-2005) on five-year-old vines grown in an experimental vineyard at the University of Idaho Parma Research and Extension Center (lat. 43 $47^{\prime} \mathrm{N}$, long. $116^{\circ} 57^{\prime} \mathrm{W}$, elevation 750 m) in Parma, ID, USA. Vineyard management reflected local commercial production practices including periodic application of herbicide, fungicide, and insecticide [17]. Rows were oriented north-south with 2 by $2.7 \mathrm{~m}$ vine and row spacing. Each own-rooted vine was double-trunked with a bilateral cordon and spur pruned to 16 buds per meter. Shoots were positioned vertically. A single nutrient application of $47.6 \mathrm{~kg}$ nitrogen (N), $39.7 \mathrm{~kg}$ of phosphorus (P) and $48.0 \mathrm{~kg}$ of potassium $(\mathrm{K}) \mathrm{ha}^{-1}$ was applied one year prior to the start of this research.

Climate at the trial site was semi-arid with precipitation providing only a quarter of crop evapotranspiration [4]. Vines were irrigated by above ground drip with 3.8 $\mathrm{L} \cdot \mathrm{h}^{-1}$, punch-in emitters located $\sim 15 \mathrm{~cm}$ on either side of the vine and drip tubing suspended $\sim 46 \mathrm{~cm}$ above the soil surface. The soil at the trial site was a Turbyfill, fine sandy loam, with a pH of 7.9 in the top 12 inches and $0.9 \%$ organic matter. The Turbyfill series is classified as a coarse-loamy, mixed, superactive, calcareous, mesic Xeric Torriorthent that formed in alluvium or lacustrine sediments on alluvial fans and terraces [18].

\subsection{Treatment and Experimental Design}

Two amounts of irrigation (well-watered or deficit-irrigated) were supplied to nine cultivars in a split-plot design with two replicated blocks. Cultivar panels contained eight consecutive vines that were randomly located within each irrigation main plot. The name and clone number of the nine cultivars evaluated in this study were Cabernet franc 01, Cabernet Sauvingnon 11, Grenache 03, Lemberger 02, Malbec 06, Merlot 08, Petite syrah 03, Viognier 01, and Sangiovese 04 (Foundation Plant Services, Davis, CA. USA). Irrigation treatments began just after fruit set (phenological stage 29) and continued until harvest [19]. The well-watered treatment supplied $100 \%$ of estimated crop evapotranspiration $\left(\mathrm{ET}_{\mathrm{c}}\right)$ and the deficit-irrigated treatment supplied $35 \%$ of $\mathrm{ET}_{\mathrm{C}}$ from pre-veraison (50\% color change and berry softening) and then $70 \% \mathrm{ET}_{\mathrm{c}}$ post-verasion. Irrigation amounts were calculated weekly using the Penman-Monteith model
[20], reference evapotranspiration (U.S. Bureau of Reclamation Parma weather station http://www.usbr.gov/pn/ agrimet/wxdata.html) and a variable crop coefficient [21].

\subsection{Tissue Sampling and Nutrient Analyses}

Tissue for nutrient analysis was collected over four growing seasons (2002-2005) following the method of Christensen [11]. Briefly, a 100 leaf sample containing blade and petiole was collected from either side of five vines in each cultivar panel between 8 and 10 am. Sampling was opposite a basal cluster at bloom and at the sixth node below the growing tip at veraison. The leaves were placed into a paper bag and transported to the laboratory where blades and petioles were separated and then dried for $72 \mathrm{~h}$ in an oven at $70^{\circ} \mathrm{C}$. Petioles sampled at bloom (2003-2005) and veraison (2002, 2004, and 2005) were analyzed for nitrate-nitrogen $\left(\mathrm{NO}_{3}-\mathrm{N}\right)$ using aqueous extraction and cadmium reduction [22] in an ion analyzer (QuikChem ${ }^{\circledR} 8000$ Lachat Instruments, Loveland CO). Blade tissue sampled at veraison $(2004,2005)$ was analyzed for phosphorus (P), potassium (K), calcium (Ca), magnesium (Mg), sodium ( $\mathrm{Na})$, boron $(\mathrm{B})$, zinc $(\mathrm{Zn})$, iron (Fe), copper $(\mathrm{Cu})$, and manganese $(\mathrm{Mg})$ after digestion in $0.5 \mathrm{~N} \mathrm{HNO}_{3}$ by inductively coupled plasma spectrophotometry and for total nitrogen (N) by combustion [23]. Tissue analysis was performed by Cascade Analytical Laboratory (Wenatchee, WA USA). Tissue samples from field replications were analyzed separately in 2004 and combined in other sampling years.

\subsection{Plant Measurements}

Vine water status was monitored weekly by measuring midday leaf water potential $\left(\Psi_{\mathrm{L}}\right)$ the day preceding each irrigation event using a pressure chamber (PMS Instruments model 610 Corvallis, OR USA) as described by Turner [24]. Two leaves in each cultivar panel were measured around solar noon. Vine growth attributes (seasonal trunk growth and shoot length), yield components (yield per vine and berry weight) and fruit maturity (soluble solids concentration, titratable acidity and $\mathrm{pH}$ ) were measured at harvest each year on vines within each cultivar panel following methods described by Shellie [4].

\subsection{Statistical Analyses}

Data were analyzed for homogeneity of variance and then analysis of variance (ANOVA) using a split-plot design with cultivars as subplots and irrigation as main plots (SAS version 8.02; SAS Institute, Cary, NC). Probability of significance for main effects and interaction terms was determined from an F test. Mean separa- 
tion for significant treatment effects was accomplished by Duncan's multiple range test and deemed to be significant at $p \leq 0.05$.

\section{RESULTS AND DISCUSSION}

\subsection{Plant Water Status and Vine Growth}

Midday $\Psi_{\mathrm{L}}$ was similar at bloom for vines in the wellwatered and deficit-irrigated treatment group, but differed subsequently after irrigation treatments were imposed at fruit set (Figure 1). The $\Psi_{\mathrm{L}}$ of deficit-irrigated vines declined between fruit set and veraison to $\sim-1.8$ MPa in three out of four years and was up to 0.6 MPa lower at veraison than well-watered vines. The difference in $\Psi_{\mathrm{L}}$ between well-watered and deficit-irrigated vines in this study was similar in magnitude to that observed by Shellie [4] and found to coincide with a reduction in leaf gas exchange and vine growth [25].

Deficit-irrigated vines had lower yield, berry weight, and fruit titratable acidity but similar juice $\mathrm{pH}$ (3.5) and percent soluble solids concentration (23.9) as well-watered vines. Yield of deficit-irrigated vines was reduced by $15 \%, 31 \%, 18 \%$, and $43 \%(6.3,4.2,5.1$, and 2.8 $\mathrm{kg} \cdot$ vine $^{-1}$ ) and berry weight was reduced by $18,6,10$, and $14 \%(0.9,1.3,1.2$, and $1.1 \mathrm{~g})$ in 2002, 2003, 2004, and 2005, respectively. Juice titratable acidity of deficitirrigated vines, averaged over four years, was $10 \%$ lower than well-watered vines (5.48 versus $6.08 \mathrm{~g} \cdot \mathrm{L}^{-1}$, respectively). Shoot length of well-watered and deficit-irrigated vines was similar at veraison $(1.3 \mathrm{~m})$ however average seasonal trunk growth of deficit-irrigated vines was 15\% less than well-watered vines ( 2.07 versus $2.45 \mathrm{~mm}$ ). Although the shoot length at veraison of deficit-irrigated and well-watered vines was similar, the reduced seasonal trunk growth and yield of deficit-irrigated vines indicates that water deficit reduced vine growth.

\subsection{Petiole and Blade Nutrients}

The petiole $\mathrm{NO}_{3}-\mathrm{N}$ concentration of vines in the wellwatered and deficit-irrigated treatment groups was similar at bloom but differed at veraison (Table 1). There was no residual effect of prior year irrigation treatment on petiole $\mathrm{NO}_{3}-\mathrm{N}$ at bloom. At veraison, deficit-irrigated vines had higher petiole $\mathrm{NO}_{3}-\mathrm{N}$ concentration than wellwatered vines. The amount of petiole $\mathrm{NO}_{3}-\mathrm{N}$ at veraison was 1 to 12 -fold higher in deficit-irrigated vines than in well-watered vines depending on the cultivar. The cultivars Grenache, Cabernet Sauvignon, Cabernet franc and Merlot had the greatest increase in petiole $\mathrm{NO}_{3}-\mathrm{N}$ concentration under water deficit.

Petiole $\mathrm{NO}_{3}-\mathrm{N}$ concentration at bloom and veraison differed significantly among cultivars. The cultivars with the greatest concentration of petiole $\mathrm{NO}_{3}-\mathrm{N}$ at bloom, were Merlot, Malbec, Grenache and Petite syrah and cultivars with lowest concentration were Lemberger, Cabernet franc, Cabernet Sauvignon and Sangiovese (Table 1). Our high ranking of "Merlot", "Malbec", "Grenache", and "Petite syrah" for petiole $\mathrm{NO}_{3}-\mathrm{N}$ was similar to findings of other researchers [13-16]. Cultivar differences in $\mathrm{NO}_{3}-\mathrm{N}$ have been related to differences in nitrate reductase (NR) activity [16].

The increase in petiole $\mathrm{NO}_{3}-\mathrm{N}$ concentration observed in this study under deficit irrigation may be due to reduced NR activity. The majority of $\mathrm{N}$ taken up by the grapevine is in the form of $\mathrm{NO}_{3}-\mathrm{N}$ and $\mathrm{N}$ is translocated in xylem and phloem as $\mathrm{NO}_{3}-\mathrm{N}$ and glutamine. Nitrate reduction by $\mathrm{NR}$ is the first step in the $\mathrm{N}$ assimilation pathway and NR activity regulates tissue nitrate concentration [16]. Stress conditions in grape are known to reduce NR activity and increase $\mathrm{NO}_{3}-\mathrm{N}$ concentration [16] while alleviation of water stress has corresponded with a decrease in grape petiole $\mathrm{NO}_{3}-\mathrm{N}$ [26]. NR activity declines in response to carbohydrate status so a water-stress

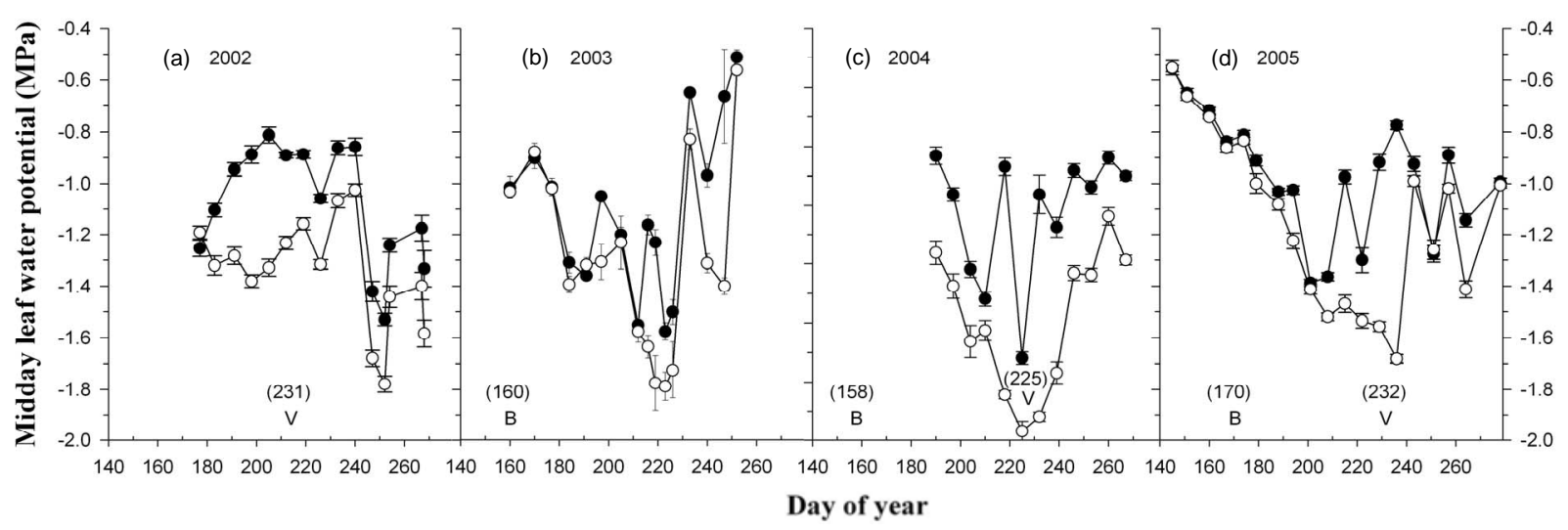

Figure 1. Midday leaf water potential of well-watered (solid circle) and deficit-irrigated (open circle) vines in 2002 (a); 2003 (b); 2004 (c); and 2005 (d). Symbols and bars depict the mean value and standard error of the mean for cv. Cabernet Sauvignon and Merlot $(\mathrm{n}=8)$. Letters indicate day of year for bloom $(\mathrm{B})$ and veraison $(\mathrm{V})$ sampling. 
Table 1. Petiole nitrate nitrogen $\left(\mathrm{NO}_{3}-\mathrm{N}\right)$ concentration of ownrooted wine grape cultivars at bloom and veraison in Parma ID. Vines were well-watered or deficit-irrigated between fruit set and veraison. Data are 3-year mean values from a split-plot analysis of variance with cultivar as subplots within each irrigation main plot.

\begin{tabular}{|c|c|c|c|}
\hline & \multicolumn{3}{|c|}{ Petiole $\mathrm{NO}_{3}-\mathrm{N}\left(\mathrm{mg} \cdot \mathrm{kg}^{-1}\right)$} \\
\hline & Bloom $^{\mathrm{a}}$ & & raison \\
\hline Cultivar & & Well-watered & Deficit-irrigated \\
\hline Merlot & $1367.8^{\mathrm{a}}$ & 309 & 1559 \\
\hline Malbec & $1253.7^{\mathrm{ab}}$ & 315 & 1042 \\
\hline Grenache & $1207.1^{\mathrm{ab}}$ & 88 & 1268 \\
\hline Petite syrah & $932.4^{\mathrm{abc}}$ & 299 & 840 \\
\hline Viognier & $629.9^{\mathrm{bcd}}$ & 195 & 359 \\
\hline Lemburger & $426.1^{\mathrm{cd}}$ & 126 & 223 \\
\hline Cabernet franc & $422.1^{\mathrm{cd}}$ & 56 & 545 \\
\hline Cabernet Sauvignon & $299.6^{\mathrm{cd}}$ & 40 & 248 \\
\hline \multirow[t]{2}{*}{ Sangiovese } & $200.4^{\mathrm{d}}$ & 37 & 177 \\
\hline & \multicolumn{3}{|c|}{ F value $^{\mathrm{a}}$} \\
\hline Irrigation (I) & NS & \multicolumn{2}{|r|}{$* *$} \\
\hline Cultivar (C) & $* *$ & \multicolumn{2}{|r|}{ ** } \\
\hline $\mathrm{C} \times \mathrm{I}$ & NS & \multicolumn{2}{|r|}{ * } \\
\hline
\end{tabular}

a,*,* NS $p \leq 0.05,0.01$, not significant. Mean separation by Duncan's multiple range test at $p \leq 0.05$. Same letter within a column indicates no significant difference. associated reduction in photosynthesis could decrease phloem carbohydrate supply and contribute to reduced NR activity.

Critical values for interpreting veraison petiole $\mathrm{NO}_{3}-\mathrm{N}$ concentration are not available, however, if bloom standards were used to interpret deficit-irrigated grape petiole $\mathrm{NO}_{3}-\mathrm{N}$ at veraison, the nitrogen status of one cultivar would be interpreted as deficient rather than adequate (Viognier), one as deficient rather than low (Lemberger) and one as adequate rather than low (Cabernet franc).

Blade $\mathrm{N}$ and $\mathrm{Cu}$ at veraison was affected by irrigation and differed among cultivars (Table 2). Deficit-irrigated vines at veraison had $\sim 6 \%$ lower blade $\mathrm{N}$ and $17 \%$ lower blade $\mathrm{Cu}$ concentration than well-watered vines. The cultivars Merlot, Malbec and Petite syrah had the greatest percent blade $\mathrm{N}$ and the cultivars Cabernet Sauvignon, Sangiovese, Viognier, and Cabernet franc had the lowest concentration. The relative ranking of blade $\mathrm{N}$ for the cultivars Merlot, Petite syrah and Grenache in this study was similar to others $[13,14]$. The maximum difference among cultivars for blade $\mathrm{N}$ concentration (20\%) was less than for petiole $\mathrm{NO}_{3}-\mathrm{N}(600 \%-800 \%)$. Blade $\mathrm{N}$ concentration at veraison was poorly correlated with petiole $\mathrm{NO}_{3}-\mathrm{N}$ at veraison $\left(\mathrm{R}^{2}=0.0771, p=0.04\right)$ or at bloom $\left(\mathrm{R}^{2}=0.2316, p=0.0002\right)$. The decrease in blade $\mathrm{N}$ observed in this study under deficit irrigation may be associated with decreased $\mathrm{N}$ uptake due to low soil moisture limiting the amount of soil solution in the active root zone and decreasing the rate of $\mathrm{N}$ mineralization of

Table 2. Veraison blade nutrient concentration in 2004 after two successive years of irrigation between fruit set and veraison under field conditions at Parma ID, USA.

\begin{tabular}{|c|c|c|c|c|}
\hline & $\mathrm{N}\left(\mathrm{g} \cdot \mathrm{kg}^{-1}\right)$ & $\mathrm{Cu}\left(\mathrm{mg} \cdot \mathrm{kg}^{-1}\right)$ & \multicolumn{2}{|c|}{$\mathrm{K}\left(\mathrm{g} \cdot \mathrm{kg}^{-1}\right)$} \\
\hline Well-watered & $24.5^{\mathrm{a}}$ & $5.1^{\mathrm{a}}$ & \multicolumn{2}{|c|}{$8.3^{\mathrm{a}}$} \\
\hline \multirow[t]{2}{*}{ Deficit-irrigated } & $22.9^{\mathrm{b}}$ & $4.2^{\mathrm{b}}$ & \multicolumn{2}{|c|}{$8.2^{\mathrm{a}}$} \\
\hline & & & Well-watered & Deficit-irrigated \\
\hline Merlot & $27.3^{\mathrm{a}}$ & $5.3^{\mathrm{a}}$ & 10.4 & 11.2 \\
\hline Malbec & $26.4^{\mathrm{ab}}$ & $5.3^{\mathrm{a}}$ & 10.2 & 9.2 \\
\hline Grenache & $24.3^{\mathrm{cd}}$ & $4.0^{\mathrm{b}}$ & 9.7 & 9.8 \\
\hline Petite syrah & $26.2^{\mathrm{abc}}$ & $3.8^{\mathrm{b}}$ & 7.8 & 6.3 \\
\hline Viognier & $21.9^{\mathrm{e}}$ & $4.3^{\mathrm{b}}$ & 7.2 & 6.0 \\
\hline Lemberger & $25.1^{\mathrm{bcd}}$ & $5.3^{\mathrm{a}}$ & 7.3 & 6.6 \\
\hline Cabernet franc & $21.9^{\mathrm{e}}$ & $4.3^{\mathrm{b}}$ & 7.7 & 9.1 \\
\hline Cabernet Sauvignon & $23.5^{\mathrm{de}}$ & $4.0^{\mathrm{b}}$ & 8.2 & 9.4 \\
\hline \multirow[t]{2}{*}{ Sangiovese } & $23.1^{\mathrm{de}}$ & $4.3^{\mathrm{b}}$ & 7.9 & 6.6 \\
\hline & & F value & & \\
\hline Irrigation (I) & ** & ** & \multicolumn{2}{|c|}{ NS } \\
\hline Cultivar (C) & $* *$ & $* *$ & \multicolumn{2}{|c|}{${ }^{* *}$} \\
\hline $\mathrm{I} \times \mathrm{C}$ & NS & NS & \multicolumn{2}{|c|}{$* *$} \\
\hline
\end{tabular}

$\overline{\mathrm{a}, *, * *}$ NS $p \leq 0.05,0.01$, not significant. Mean separation by Duncan's multiple range test at $p \leq 0.05$. Same letter within a treatment level are not significantly different. 
soil organic $\mathrm{N}$.

The influence of water deficit on the interpretation of blade $\mathrm{N}$ or $\mathrm{Cu}$ is not likely to be of practical importance because reductions observed under the conditions of this study under water deficit (6\% and $13 \%$ ) were of lesser magnitude than their corresponding interpretive standard's margin of deficiency (27\% and 50\%) [9]. Cultivar differences in tissue nutrient concentration under the well-watered conditions in this study over sequential seasons provide further evidence of the importance of genotype on the practical interpretation of tissue nutrient analyses.

Blade $\mathrm{K}$ concentration at veraison varied according to cultivar in response to water deficit (Table 2). Deficitirrigated vines had lower (cv. Malbec, Petite syrah, Viognier, and Sangiovese), higher (cv. Cabernet Sauvignon and Cabernet franc), or similar (cv. Grenache, Merlot and Lemberger) blade $\mathrm{K}$ concentration as well-watered vines. Potassium is phloem mobile and important for vine productivity, however, high levels can adversely affect wine quality by raising fruit juice $\mathrm{pH}$ or precipitating potassium tartrate [27]. Water deficit has been reported to decrease [28,26] or have no effect [29] on blade K. An opposite response to irrigation rate in the cultivar Merlot compared to Cabernet Sauvignon has also been observed by others [30]. Our results suggest that deficit irrigation exacerbates the difficulty of interpreting tissue $\mathrm{K}$ concentration, especially if tissue values are in the low range of adequate since small differences in concentration $(\leq$ $0.2 \%$ ) are associated with visible deficiency symptoms [31].

Blade concentrations of $\mathrm{P}, \mathrm{Ca}, \mathrm{Mg}, \mathrm{Na}, \mathrm{Zn}, \mathrm{Fe}$, and $\mathrm{Mn}$ at veraison were not influenced by irrigation regime but differed among cultivars (data not shown). No significant cultivar differences were observed in blade $\mathrm{B}$ concentration. "Merlot" ranked at or near the top and "Sangiovese" at or near the bottom of the list, respectively, for all nutrients analyzed other than Zn.

\section{CONCLUSION}

A major goal of nutrient management in wine grape is to achieve a sustained yield of fruit containing sufficient nutrients (especially nitrogen and potassium) to support yeast growth during fermentation. The type of tissue and timing of sampling that best predicts vine nutrient status under differing production practices and environmental conditions remains controversial. This study provides data showing that petiole sampling at veraison to assess wine grape nutrient status is influenced by irrigation practices and therefore cannot provide the information needed to guide $\mathrm{N}$ and $\mathrm{K}$ nutrient management decisions. This is particularly relevant to semi-arid regions where deficit irrigation practices are commonly used to opti- mize water use efficiency and berry composition and limit vigor expression. The different response to irrigation amount in petiole $\mathrm{NO}_{3}-\mathrm{N}$ and blade $\mathrm{N}$ and $\mathrm{K}$ concentrations observed among cultivars also demonstrates a need for cultivar-specific interpretation standards or alternative diagnostic procedures.

\section{ACKNOWLEDGEMENTS}

The authors gratefully acknowledge the logistical and technical support of Chris Rennaker and Jeff Acock. This research was conducted using base CRIS funds from the ARS.

\section{REFERENCES}

[1] During, H. (1987) Stomatal responses to alterations in soil and air humidity in grapevines. Vitis, 26, 9-18.

[2] Jackson, D.I. and Lombard, P.B. (1993) Environmental and management practices affecting grape composition and wine quality-A review. American Journal of Enology and Viticulture, 44, 409-430.

[3] Padgett-Johnson, M., Williams, L.E. and Walker, M.A. (2003) Vine water relations, gas exchange, and vegetative growth of seventeen Vitis species grown under irrigated and nonirrigated conditions in California. Journal of the American Society for Horticultural Science, 128, 269-276.

[4] Shellie, K.C. (2006) Vine and berry response of Merlot (Vitis vinifera) to differential water stress. American Journal of Enology and Viticulture, 57, 514-518.

[5] Castellarin, S.D., Pfeiffer, A., Sivilotti, P., Degan, M., Peterlunger, E. and Di Gaspero, G. (2007) Transcriptional regulation of anthocyanin biosynthesis in ripening fruits of grapevine under seasonal water deficit. Plant, Cell \& Environment, 30, 1381-1399. doi:10.1111/j.1365-3040.2007.01716.x

[6] Bravdo, B.A. (2007) Effect of irrigation and fertilization on fruit and wine quality. Acta Horticulturae, 754, 265274.

[7] Davenport, J.R., Stevens, R.G. and Whitley, K.M. (2008) Spatial and temporal distribution of soil moisture in dripirrigated vineyards. HortScience, 43, 229-235.

[8] Keller, M. (2005) Deficit irrigation and vine mineral status. American Journal of Enology and Viticulture, 56, 267-283.

[9] Robinson, J.B. (1999) Grape nutrition. In: Coombe, B.G. and Dry, P.R., Eds., Viticulture, Volume 2, Practices, Hyde Park Press, Adelaide, 178-208.

[10] Robinson, J.B. (2004) Critical plant tissue values and application of nutritional standards for practical use in vineyards. In: Christensen, L.P. and Smart, D.R., Eds., Proceedings of the Soil Environment and Vine Mineral Nutrition Symposium, American Society for Enology and Viticulture, Davis, 61-68.

[11] Christensen, P. (2005) Use of tissue analysis in viticulture. Cooperative Extension Pub. NG10-00. University of California, Tulare County, Visalia,.

[12] Cook, J.A. and Lider, L.A. (1964) Mineral composition 
of blooming grape petiole in relation to rootstock and scion variety behavior. American Society for Horticultural Science, 84, 243-254.

[13] Christensen, P. (1984) Nutrient level comparison of leaf petioles and blades in twenty-six grape cultivars over three years. American Journal of Enology and Viticulture, 35, 124-133.

[14] Fallahi, E., Shaffi, B., Stark, J.C. and Fallahi, B. (2005) Cane and leaf growth and leaf mineral nutrients in various cultivars of wine grapes. Journal of the American Pomological Society, 59, 182-191.

[15] Fallahi, E., Shafii, B., Stark, J.C., Fallahi, B. and Hafez, S.I. (2005) Influence of wine grape cultivars on growth and leaf blade and petiole mineral nutrients. HortTechnology, 15, 825-830.

[16] Perez, J.R. and Kliewer, W.M. (1982), Influence of light regime and nitrate fertilization on nitrate reductase activity and concentrations of nitrate and arginine in tissues of three cultivars of grapevines. American Journal of Enology and Viticulture, 33, 86-93.

[17] Watson, J. (1999) Washington viticulture-The basics. In: Watson, J. Ed., Growing Grapes in Eastern Washington. Proceedings from a Washington State University Shortcourse on Establishing a Vineyard and Producing Grapes, Good Fruit Grower, Yakima, 13-20.

[18] USDA-NRCS (2009) Official soil series descriptions. http://ortho.ftw.nrcs.usda.gov/cgi-bin/osd/osdname.cgi

[19] Coombe, B.G. (1995) Growth stages of the grapevineThe modified E-L system. Australian Journal of Grape and Wine Research, 1, 100-110.

[20] Allen, R.G., Pereira, L.S., Raes, D. and Smith, M. (1998) Crop Evapotranspiration. Guidelines for Computing Crop Water Requirements. Irrigation and Drainage Paper 56. FAO Rome.

[21] Evans, R.G., Spayd, S.E., Wample, R.L., Kroeger, M.W. and Mahan, M.O. (1993) Water use of Vitis vinifera grapes in Washington. Agricultural Water Management, 23, 109-124.

\section{doi:10.1016/0378-3774(93)90035-9}

[22] Hanson, D., Kotuby-Amacher, J. and Miller, R.O. (1998) Soil analysis: Western states proficiency testing program for 1996. Analytical Chemistry, 360, 348-350.

[23] Nelson, D.W. and Sommers, L.E. (1996) Total carbon, organic carbon and organic matter. In: Sparks, D.I. Ed., Methods of Soil Analysis, Part 3-Chemical Methods, Soil Science Society of America, Madison, 975-977.

[24] Turner, N.C. (1988) Measurement of plant water status by the pressure chamber technique. Irrigation Science, 9, 289-308. doi:10.1007/BF00296704

[25] Shellie, K.C. and Glenn, D.M. (2008) Wine grape response to foliar particle film under differing levels of preveraison water stress. HortScience, 43, 1392-1397.

[26] Cook, J.A. (1961) Some problems in determining nitrogen needs in California vineyards. Wine and Vines, 42, 30 .

[27] Somers, T.C. (1975) In search of quality red wines. Food Technology in Australia, 27, 49-56.

[28] Hepner, Y. and Bravdo, B. (1985) Effect of crop level and drip irrigation scheduling on the $\mathrm{K}$ status of Cabernet Sauvignon and Carignane vines and its influence on must and wine composition and quality. American Journal of Enology and Viticulture, 36, 140-147.

[29] Morris, J.R. and Cawthon, D.L. (1982) Effect of irrigation, fruit load, and potassium fertilization on yield, quality, and petiole analysis of concord (Vitis labrusca L.) grapes. American Journal of Enology and Viticulture, 33, 145-148.

[30] Klein, I., Strime, M., Fanberstein, L. and Mani, Y. (2000) Irrigation and fertigation effects on phosphorus and potassium nutrition of wine grapes. Vitis, 39, 55-62.

[31] Poni, S., Quartieri, M. and Tagliavani, M. (2003) Potassium nutrition of Cabernet Sauvignon grapevines (Vitis ninifera L.) as affected by shoot trimming. Plant and Soil, 253, 341-351. doi:10.1023/A:1024832113098 